\title{
Trace Metal Accumulation in Tissue of Sea Cucumber Species; North-Western Sea of Sri Lanka
}

\author{
Jinadasa B.K.K.K. ${ }^{1, *}$, Samanthi R.I. ${ }^{2}$, Wicramsinghe I. $^{2}$ \\ ${ }^{1}$ Institute of Post Harvest Technology, National Aquatic Resources Research and Development Agency, Crow Island, Mattakkuliya, \\ Colombo 15, Sri Lanka \\ ${ }^{2}$ Department of Food Science and Technology, Faculty of Applied Sciences, University of Sri Jayewardenepura, Nugegoda, Sri Lanka \\ *Corresponding author: jinadasa76@gmail.com
}

Received September 05, 2014; Revised September 15, 2014; Accepted September 21, 2014

\begin{abstract}
The presence of copper (Cu), iron (Fe), zinc ( $\mathrm{Zn}$ ), lead (Pb), cadmium (Cd), cobalt (Co), chromium (Cr) and mercury $(\mathrm{Hg})$ has been studied in ten sea cucumber (Holothurians) species in the Northwestern sea of Kalpitiya and Dutch Bay area (Sri Lanka) during October- November 2008 and 2009. The concentration of in holothurians body wall have been found to range from $1.84-9.18 \mathrm{mg} / \mathrm{kg}(\mathrm{Cu}), 5.03-56.68 \mathrm{mg} / \mathrm{kg}(\mathrm{Fe}), 3.68-24.38 \mathrm{mg} / \mathrm{kg}(\mathrm{Zn})$, $<0.04-4.70 \mathrm{mg} / \mathrm{kg}(\mathrm{Cr}), 0.04-2.29 \mathrm{mg} / \mathrm{kg}(\mathrm{Pb}), 41.62-128.93 \mu \mathrm{g} / \mathrm{kg}(\mathrm{Cd}), 0.07-0.25 \mathrm{mg} / \mathrm{kg}$ (Co) and 24.63-445.69 $\mu \mathrm{g} / \mathrm{kg}(\mathrm{Hg})$ in dry weight basis. The results show that, according to European legislation, the body wall of holothurians is generally "safe", although the high levels of iron in all holothurians are noticeable.
\end{abstract}

Keywords: Holothurians, trace metals, Sri Lanka

Cite This Article: Jinadasa B.K.K.K., Samanthi R.I., and Wicramsinghe I., "Trace Metal Accumulation in Tissue of Sea Cucumber Species; North-Western Sea of Sri Lanka.” American Journal of Public Health Research, vol. 2, no. 5A (2014): 1-5. doi: 10.12691/ajphr-2-5A-1.

\section{Introduction}

Sea cucumbers are called Holothurians and locally known as "MuhuduKekiri" in Sinhalese and "Atta" in Tamil. These are very curious animals, having the form of an elongated and worm-like cylinder, sometimes straight, sometimes curved. Their size varies from one to forty inches, the larger size being the most common (Tandon and Henry, 1882).

Sea cucumbers, also known as sea slugs, are a highly appreciated delicacy in most Asian countries and in countries where ethnic Chinese communities exist (Catharina et al., 1999). Holothurians are traditionally consumed raw, dried, and boiled as food for human consumption (Nil et al., 2004). They are used for soups and salads and served as a traditional food at special occasions like New Year celebrations, because consumers believe in high medicinal value of them. Major producing countries of sea cucumbers include Japan, Korea, Sri Lanka, Indonesia, India, Malaysia and the Philippines (Catharina et al., 1999). Sri Lanka produces a small volume of higher value production and it creates a high market demand for Sri Lankan products. In 2010, Sri Lanka has exported 178 MT of sea cucumber and earned 649 million rupees (MOFAR, 2011). That value was 1\% of the total fish export quantity and $3.3 \%$ of total fish export value. There are nearly 200 known species of sea cucumber in the ocean around Sri Lanka. About 75 species have been shown to be present in shallow waters while nearly 50 species can be collected from the intertidal region (Clark and Rowe, 1971, Dissanayake, et al., 2007, 2010).

Trace elements pass into the environment and enter the marine ecosystem because of weathering and erosion. In recent years, human activities have emitted various trace elements into ambient environments from agricultural runoff, industrial processes and accidental spills (Pugh and Becker, 2001, Maria et al, 2011, Pacyna, et al., 2001). Many marine animals can accumulate heavy metals such as zinc, mercury, copper, cadmium and lead in their body. Three commercially important groups of marine animals (mollusks, crustaceans and teleosts) have been frequently studied for bioaccumulation of heavy metals (Xing \& Chia, 1997). In molluscs, it has been found that heavy metal accumulation positively correlates with the metal concentration in the diet and ambient water (Julshamn \& Grahl-Nielsen, 1996).

Marine sediment plays a major role as the reservoir of heavy metals because most of the trace metals can be trapped by the sediment particles (Luoma, 1990, Woodwell, et al., 1971). Sediment particles passing through the guts of deposit feeders are subject to an environment unusually rich in dissolved organic material, especially proteinaceous materials, capable of binding metals (Chen et al, 2000).

There are several studies on the bioaccumulation of trace elements in marine ecosystems (Adachi et al, 2012). Nevertheless the general bioaccumulation pattern of heavy metals in marine organisms has not been established. Therefore, it is necessary to accumulate data from various marine ecosystems. Even though sea cucumbers of Sri Lanka have a high demand in the export market, there is 
no adequate information about metal concentration of them. Metals such as chromium (Cr), iron (Fe), cobalt $(\mathrm{Co})$, copper $(\mathrm{Cu})$ and zinc $(\mathrm{Zn})$ are currently known or thought to be required for normal biological functions in humans (Bertini, et al., 1998). But adverse health effects and toxicity may arise from excessive quantities of these metals. Heavy metals such as mercury (Hg), cadmium (Cd) and lead $(\mathrm{Pb})$ are non-essential metals as they are toxic even in traces (Turkmen et al., 2007). Due to pollution in the marine environment, bioaccumulation of metals in marine organisms has increased.

This study was designed to determine the metal concentration of sea cucumber species in Sri Lanka and to identify whether the accumulation of metal varies according to the species of sea cucumber.

\section{Materials and Methods}

\subsection{Sampling}

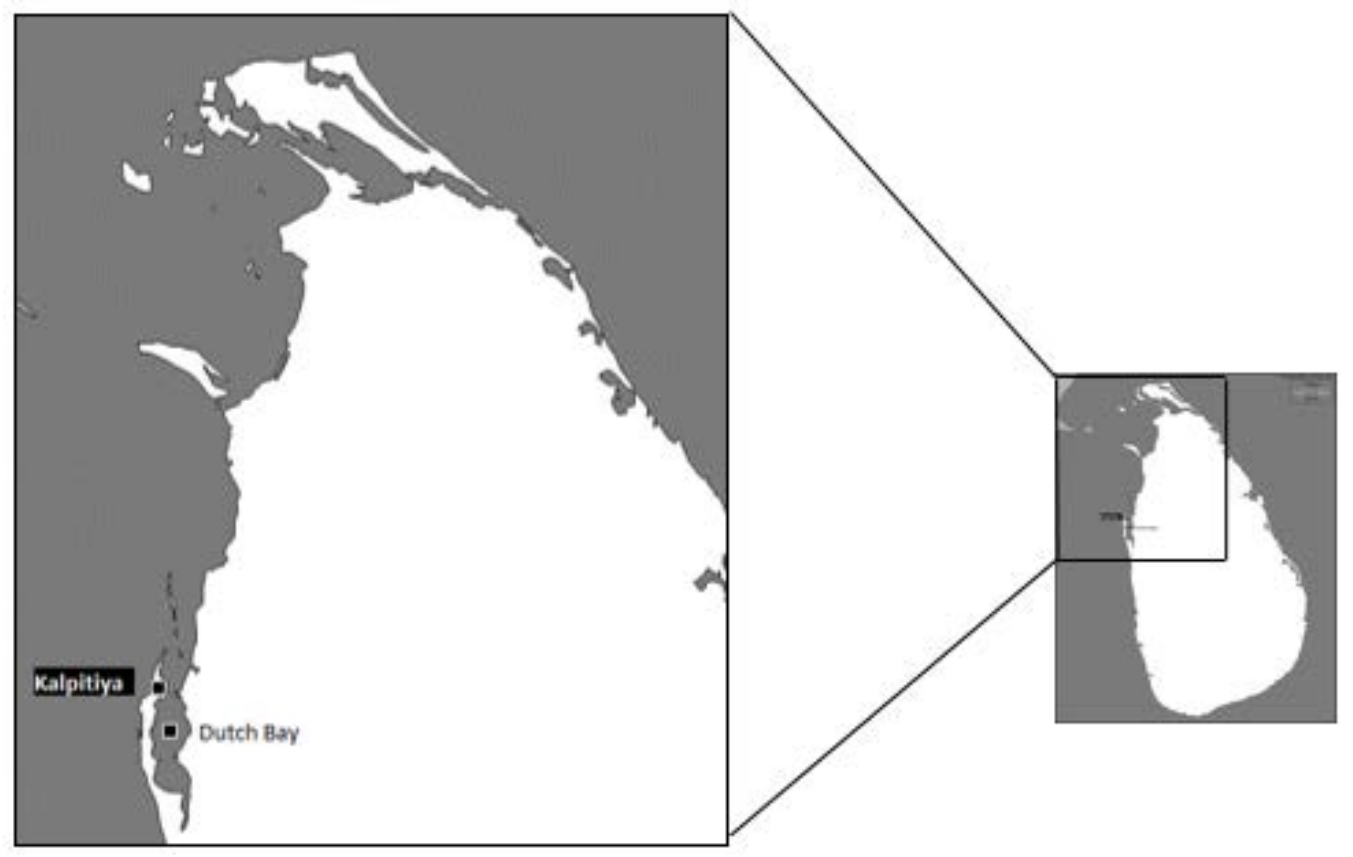

Figure 1. Map of sampling area

\subsection{Sample Preparation}

The body wall of sea cucumber was cut along the length to remove all the internal organs before analysis and only the body wall was used for analysis after cleaning. Sea cucumber tissues were dried at $105^{\circ} \mathrm{C}$ until a constant dry weight was obtained to determine the moisture content (AOAC official method 950.46).Then, they were packed in labelled polyethylene bags and kept in the refrigerator until used for metal analysis. The ash content of the samples was analysed by AOAC official method 920.153. Each dried sample was digested using amicrowave-assisted digester oven (Mars CEM XP-1500+, Mathhews, USA) using $10 \mathrm{~mL}$ of conc. $\mathrm{HNO}_{3}$ (SigmaAldrich, St. Louis, MO, USA). Two blank samples and two matrices-spiked samples ( $\mathrm{Pb}, \mathrm{Zn}, \mathrm{Fe}, \mathrm{Co}$ and $\mathrm{Cr}$ ) were digested for each batch. Standard quality control materials T/0774 from FAPAS (Food Analysis Performance Assessment Scheme, The Food and Environment
Sea cucumber samples were collected from Kalpitiya and Dutch Bay sea area in Sri Lanka during OctoberNovember 2008 and October- November 2009 (Figure 1). One hundred and forty four (144) samples of Holothuriaedulis (Pinkfish, $\mathrm{n}=48$ ), H. atra (Lollyfish, $\mathrm{n}=18$ ), Thelenotaanax (Amberfish, $\mathrm{n}=10$ ), H. scabra (Sandfish, $\mathrm{n}=8$ ), H. spinifera (Brown sandfish, $\mathrm{n}=14$ ), Bohadschia sp. (unidentified, $\mathrm{n}=12$ ), Bohadschiasimilis (Brown spotted sandfish, n=8), B. marmorata (Chalkyfish, $\mathrm{n}=14$ ), Actinopygamiliaris (Blackfish, $\mathrm{n}=6$ ) and Stichopuschloronotus (Greenfish, $\mathrm{n}=6$ ) were collected by random diving and they were eviscerated immediately after harvesting. Evisceration was done by cutting the anus and pressing the body wall firmly to remove viscera. Then they were stored in ice and delivered to the Analytical Chemistry Laboratory at the National Aquatic Resources Research and Development Agency (NARA) covered with ice in insulated boxes. The samples were packed in polyethylene bags and stored in freezer until used for further analysis. 


\subsection{Data Analysis}

The results were statistically analysed by Microsoft Excel 2003 and MINITAB 14. A one- way Analysis of Variance (ANOVA) was performed, followed by Tukey’s test for comparisons of significant differences.

\section{Results and Discussion}

Quality assurance procedures included the use of analytical grade reagents, method blanks and matrix spikes. The suitability of the analytical method was evaluated in terms of their respective limits of detection $(\mathrm{LOD}=$ mean blank+3S), precision and recoveries using spiked samples. The recoveries were maintained between $80-120 \%$ and the relative standard deviation (RSD) values were less than $15 \%$. Data on standard quality control materials are and spiked samples are shown in Table 1. The results obtained from spiked sea cucumber samples and quality control material results indicated that the methods used were suitable for the determination of metal concentrations in the samples investigated. The expanded uncertainty was calculated value of all metals below $20 \%$. ( $\mathrm{U}=\mathrm{S}_{\overline{\mathrm{x}}} \mathrm{x} \mathrm{k}$; here $\mathrm{S}_{\overline{\mathrm{x}}}$ is the standard deviation of the predicted concentration and $\mathrm{k}$ is the coverage factor).

Table 1. Determined values, certified values, recovery \% of quality control samples (T0774) and spiked recovery values (n=10)

\begin{tabular}{|c|c|c|c|c|c|c|c|c|}
\hline & $\mathrm{Hg}(\mu \mathrm{g} / \mathrm{kg})$ & $\mathrm{Cu}(\mu \mathrm{g} / \mathrm{kg})$ & $\mathrm{Cd}(\mu \mathrm{g} / \mathrm{kg})$ & $\mathrm{Pb}(\mu \mathrm{g} / \mathrm{kg})$ & $\mathrm{Fe}(\mathrm{mg} / \mathrm{kg})$ & $\mathrm{Zn}(\mathrm{mg} / \mathrm{kg})$ & $\mathrm{Cr}(\mu \mathrm{g} / \mathrm{kg})$ & $\mathrm{Co}(\mu \mathrm{g} / \mathrm{kg})$ \\
\hline Certified value & 19.9 & 726 & 2.59 & - & - & - & - & - \\
\hline Determined value & 20.0 & 743 & 2.61 & - & - & - & - & - \\
\hline \% Recovery & 100.48 & 102 & 100.73 & 89.5 & 96.78 & 103.64 & 92.53 & 83.65 \\
\hline
\end{tabular}

The results obtained from the analysis were tabulated in Table 2. The moisture content of analyzed species was within the range of $76.91-91.27 \%$. H.spinifera had the lowest mean moisture content of $76.91 \%(\mathrm{P}<0.05)$ and $S$. chloronotus had the highest mean moisture content of 91.27\% $(\mathrm{P}<0.05)$. The ash content of the analyzed species

was within the range of $2.61-12.04 \%$. The $H$. atra had the lowest meanash content of $2.61 \%$. Among the analysed species, $H$. spinifera had the highest mean ash content of $12.04 \%$. Same results for dry matter were observed for $H$. tubulosa and H. polii (Sicuro, et al., 2012).

Table 2. Mean concentration of metals in analyzed sea cucumber species in dry weight basis ( \pm SD)

\begin{tabular}{|c|c|c|c|c|c|}
\hline Metal & H. edulis & H. atra & T. anax & B.marmorata & S. chloronotus \\
\hline $\mathrm{Cu}$ (mg/Kg) & $1.84( \pm 3.71)$ & $3.18( \pm 1.02)$ & $2.92( \pm 0.82)$ & $2.81( \pm 1.02)$ & $7.25( \pm 8.49)$ \\
\hline $\mathrm{Fe}(\mathrm{mg} / \mathrm{Kg})$ & $\begin{array}{c}39.82 \\
( \pm 23.17)\end{array}$ & $\begin{array}{c}11.72 \\
( \pm 12.11)\end{array}$ & $\begin{array}{c}53.82 \\
( \pm 30.98)\end{array}$ & $\begin{array}{c}23.06 \\
( \pm 8.23)\end{array}$ & $\begin{array}{c}39.51 \\
( \pm 8.84)\end{array}$ \\
\hline Zn (mg/Kg) & $\begin{array}{c}20.95 \\
( \pm 6.75) \\
\end{array}$ & $\begin{array}{c}24.38 \\
( \pm 3.96) \\
\end{array}$ & $\begin{array}{c}22.81 \\
( \pm 7.51) \\
\end{array}$ & $\begin{array}{c}16.06 \\
( \pm 12.06)\end{array}$ & $\begin{array}{c}16.20 \\
( \pm 2.71)\end{array}$ \\
\hline $\mathrm{Pb}(\mu \mathrm{g} / \mathrm{Kg})$ & $\begin{array}{c}33.70 \\
( \pm 112.20)\end{array}$ & $\begin{array}{c}97.52 \\
( \pm 75.14)\end{array}$ & $\begin{array}{c}297.57 \\
( \pm 479.55)\end{array}$ & $\begin{array}{c}227.02 \\
( \pm 193.89)\end{array}$ & $\begin{array}{c}683.36 \\
( \pm 253.27)\end{array}$ \\
\hline Cd $(\mu \mathrm{g} / \mathrm{Kg})$ & $\begin{array}{c}114.47 \\
( \pm 76.01)\end{array}$ & $\begin{array}{c}72.52 \\
( \pm 8.88) \\
\end{array}$ & $\begin{array}{c}84.51 \\
( \pm 22.41) \\
\end{array}$ & $\begin{array}{c}137.00 \\
( \pm 29.32) \\
\end{array}$ & $\begin{array}{c}86.11 \\
( \pm 25.37) \\
\end{array}$ \\
\hline Co $(\mu \mathrm{g} / \mathrm{Kg})$ & $\begin{array}{c}0.13 \\
( \pm 0.10) \\
\end{array}$ & $\begin{array}{c}0.09 \\
( \pm 0.06) \\
\end{array}$ & $\begin{array}{c}0.19 \\
( \pm 0.03)\end{array}$ & $\begin{array}{c}0.07 \\
( \pm 0.03) \\
\end{array}$ & $\begin{array}{c}0.25 \\
( \pm 0.02) \\
\end{array}$ \\
\hline $\mathrm{Cr}(\mu \mathrm{g} / \mathrm{Kg})$ & $\begin{array}{c}3.00 \\
( \pm 1.85)\end{array}$ & $<0.04$ & $\begin{array}{c}0.20 \\
( \pm 0.16)\end{array}$ & $\begin{array}{c}0.46 \\
( \pm 0.12) \\
\end{array}$ & $\begin{array}{c}0.99 \\
( \pm 0.18)\end{array}$ \\
\hline Hg ( $\mu \mathrm{g} / \mathrm{Kg})$ & $\begin{array}{c}24.63 \\
( \pm 16.76) \\
\end{array}$ & $\begin{array}{c}31.32 \\
( \pm 12.82) \\
\end{array}$ & $\begin{array}{c}28.67 \\
( \pm 5.99) \\
\end{array}$ & $\begin{array}{c}116.22 \\
( \pm 129.74)\end{array}$ & $\begin{array}{c}243.28 \\
( \pm 59.32)\end{array}$ \\
\hline Metal & H. scabra & Bohadschia sp. & H. spinifera & A. miliaris & B. similis \\
\hline $\mathrm{Cu}(\mathrm{mg} / \mathrm{Kg})$ & $3.45( \pm 1.00)$ & $4.30( \pm 3.66)$ & $4.42( \pm 3.12)$ & $9.18( \pm 2.14)$ & $5.70( \pm 0.67)$ \\
\hline $\mathrm{Fe}(\mathrm{mg} / \mathrm{Kg})$ & $\begin{array}{c}5.03 \\
( \pm 5.35) \\
\end{array}$ & $\begin{array}{c}55.46 \\
( \pm 59.51)\end{array}$ & $\begin{array}{c}20.09 \\
( \pm 12.79)\end{array}$ & $\begin{array}{c}43.58 \\
( \pm 12.15)\end{array}$ & $\begin{array}{c}56.68 \\
( \pm 17.77) \\
\end{array}$ \\
\hline Zn (mg/Kg) & $\begin{array}{c}3.68 \\
( \pm 0.45)\end{array}$ & $\begin{array}{c}12.68 \\
( \pm 5.18)\end{array}$ & $\begin{array}{c}8.77 \\
( \pm 3.07)\end{array}$ & $\begin{array}{c}12.11 \\
( \pm 2.90)\end{array}$ & $\begin{array}{c}16.22 \\
( \pm 6.26)\end{array}$ \\
\hline $\mathrm{Pb}(\mu \mathrm{g} / \mathrm{Kg})$ & $\begin{array}{c}34.71 \\
( \pm 47.74) \\
\end{array}$ & $\begin{array}{c}491.64 \\
( \pm 437.10)\end{array}$ & $\begin{array}{c}204.56 \\
( \pm 480.47)\end{array}$ & $\begin{array}{c}2287.05 \\
( \pm 917.15) \\
\end{array}$ & $\begin{array}{c}450.53 \\
( \pm 291.31) \\
\end{array}$ \\
\hline $\mathrm{Cd}(\mu \mathrm{g} / \mathrm{Kg})$ & $\begin{array}{c}41.62 \\
( \pm 6.95) \\
\end{array}$ & $\begin{array}{c}128.93 \\
( \pm 44.86) \\
\end{array}$ & $\begin{array}{c}48.23 \\
( \pm 12.42) \\
\end{array}$ & $\begin{array}{c}52.66 \\
( \pm 13.61) \\
\end{array}$ & $\begin{array}{c}54.97 \\
( \pm 30.79)\end{array}$ \\
\hline Co $(\mu \mathrm{g} / \mathrm{Kg})$ & $\begin{array}{c}0.12 \\
( \pm 0.03) \\
\end{array}$ & $\begin{array}{c}0.16 \\
( \pm 0.09) \\
\end{array}$ & $\begin{array}{c}0.08 \\
( \pm 0.06)\end{array}$ & $\begin{array}{c}0.08 \\
( \pm 0.03) \\
\end{array}$ & $\begin{array}{c}0.09 \\
( \pm 0.02) \\
\end{array}$ \\
\hline $\mathrm{Cr}(\mu \mathrm{g} / \mathrm{Kg})$ & $\begin{array}{c}0.59 \\
( \pm 0.22)\end{array}$ & $\begin{array}{c}1.17 \\
( \pm 0.66)\end{array}$ & $\begin{array}{c}1.31 \\
( \pm 0.42)\end{array}$ & $\begin{array}{c}3.85 \\
( \pm 2.06)\end{array}$ & $\begin{array}{c}4.70 \\
( \pm 2.71)\end{array}$ \\
\hline $\mathrm{Hg}(\mu \mathrm{g} / \mathrm{Kg})$ & $\begin{array}{c}445.69 \\
( \pm 196.32)\end{array}$ & $\begin{array}{c}166.33 \\
( \pm 52.51)\end{array}$ & $\begin{array}{c}133.70 \\
( \pm 96.33) \\
\end{array}$ & $\begin{array}{c}72.84 \\
( \pm 12.08) \\
\end{array}$ & $\begin{array}{c}127.03 \\
( \pm 41.46)\end{array}$ \\
\hline
\end{tabular}

Mean values of $\mathrm{Cu}$ ranged from $1.84 \mathrm{mg} / \mathrm{kg}$ to 9.18 $\mathrm{mg} / \mathrm{kg}$. Of the ten species studied, $H$. edulis had the lowest mean concentration and $S$. chloronotus had the highest mean concentration of copper. The mean values of $\mathrm{Fe}$ ranged between 5.03 and $56.68 \mathrm{mg} / \mathrm{kg}$ dry weight. The lowest value of Fe was founded in H.Scabra $(5.03 \mathrm{mg} / \mathrm{kg})$ and $B$. similis had the highest value of $\mathrm{Fe}(56.68$ $\mathrm{mg} / \mathrm{kg}$ ). Mean concentrations of $\mathrm{Zn}$ were in the range of 3.68 (H. scabra) - 24.38 (H. Atra) mg/kg dry weight. The $\mathrm{Pb}$ level was highest in $S$. chloronotus $(683.36 \mu \mathrm{g} / \mathrm{kg})$ and 
lowest by $H$. edulis $(33.70 \mu \mathrm{g} / \mathrm{kg})$.Mean concentrations of Cd were within the range of 41.62 (H. scabra) - 137.00 $\mu \mathrm{g} / \mathrm{kg}$ (B. marmorata) in dry weight. Ray and Kiceniuk (1994) reported that the bioaccumulation trend of Cd among aquatic organisms was in the order of mollusks $\left(10^{3}-10^{4}\right)$, crustaceans $\left(10^{3}\right)$ and fish $\left(10^{2}\right)$. The mean values of Co were between the ranges of $0.07-0.25 \mathrm{mg} / \mathrm{kg}$ in B. marmorata and S. chloronotus respectively. All the mean values of $\mathrm{Cr}$ were below the detection limit (0.04 $\mathrm{mg} / \mathrm{kg}$ ) of $H$. atra and highest in $4.70 \mathrm{mg} / \mathrm{kg}$ in B. similis. Of the ten species of sea cucumber analysed for their total $\mathrm{Hg}$ content, the amount of $\mathrm{Hg}$ in the samples was highest in the $H$. scabra (445. $69 \mu \mathrm{g} / \mathrm{kg})$, followed by $S$. chloronotus $(243.28 \mu \mathrm{g} / \mathrm{kg})$. The lowest value of total $\mathrm{Hg}$ concentration of $24.63 \mu \mathrm{g} / \mathrm{kg}$ recorded in the $H$. edulis. Mercury has been known to accumulate in the tissues of marine organisms, which are predatory in nature. In the marine environment, methyl Hg enters the food chain first via filter-feeding organisms and gradually gets concentrated higher up the food chain (Reilly, 1991). Mercury is deposited naturally in the marine sediment and sea cucumbers that spend their lives buried in sediments could have absorbed $\mathrm{Hg}$ by direct assimilation from the surrounding medium. In this study, only the total $\mathrm{Hg}$ content was determined.

Trace metals can contaminate sea cucumber through different sources: they can accumulate in sea cucumber through feed consumption or due to pollution of the seas or they can migrate from an object used in contact with food in the food. The body compartment, sampling location and sampling depth usually significantly affected metal concentrations in the different compartments of Holothurians(Michel et al, 2006), but in this study sample were analysed only by species separation, without considering the depth distribution. In a similar study, Michel et al (2006), reported that there are no important relationships between concentrations of a given metal in different compartments or between concentrations of different metals in a given compartment. Another thing is sea cucumber has long life, 4-8 years and they are deposited feeder; they can accumulate trace metals eventually sediments where they live consequently trace metals content have been investigated in another study (Michel et al., 2006, Sicuro, et al., 2012). Of the main three toxic metals $\mathrm{Hg}, \mathrm{Cd}$ and $\mathrm{Pb}$; $\mathrm{Pb}$ concentration was quite higher in studied sea cucumber species. Lead has a well-known affinity for calcic skeletons and has been shown to be predominantly concentrated in the body walls of several echinoderms (Beeby, 1991). However, laboratory experiments have shown that holothurians do quite efficiently concentrate metals and radio nuclides such as Am, Co, Pu and V (Michel et al, 2006). According to the literature, the sea cucumber gut generally concentrates the investigated metals, most probably, and the body wall contains the major part (75-87\%) of the total element load of the organism. In addition, holothurians depurate these elements relatively slowly (half-lives ranging from 51 to 130 days according to the element), suggesting that they could act as integrators of metal and radionuclide contamination in the environment (Michel et al., 2006).

The heavy metal (mg/kg, dry weight basis) content of the sea cucumber body wall has variously been reported in previous studies and these findings are given in Table 3. In the present study the concentration of toxic trace metals like $\mathrm{Hg}, \mathrm{Cd}$ and $\mathrm{Pb}$ in sea cucumber species were low and the levels were below the limits of Sri Lankan export regulations (No. 1528/7, 2007).

Table 3. Investigated trace metal levels in sea cucumber sp in previous studies.

\begin{tabular}{|l|c|c|c|c|c|c|c|c|}
\hline Species & $\mathrm{Hg}$ & $\mathrm{Zn}$ & $\mathrm{Pb}$ & $\mathrm{Cd}$ & $\mathrm{Fe}$ & $\mathrm{Cr}$ & $\mathrm{Cu}$ & $\mathrm{Reference}$ \\
\hline H. tunulosa & & 15.37 & 4.71 & 1.27 & 52.07 & - & 1.48 & Michel et al., 2006 \\
\hline Asticopusmultifidisum & & - & 0.146 & 0.416 & - & 0.17 & 0.226 & Medina et al., 2004 \\
\hline Isostichopusbadionotos & & - & 4.311 & 0.795 & - & 0.326 & 1.01 & Medina et al., 2004 \\
\hline H. floridana & & - & 2.047 & 2.731 & - & 0.988 & 1.047 & Medina et al., 2004 \\
\hline B. mormorata & 2.89 & 41.5 & 0.88 & 0.08 & & 0.56 & 1.50 & Denton et al., 2009 \\
\hline H. atra & 1.83 & 13.8 & 1.79 & & & 0.37 & 1.27 \\
\hline H. leucospilota & & 8.14 & - & - & - & & 2.11 & Jun, X. (1998) \\
\hline H. tubulosa & & 17.40 & 1.16 & 0.07 & 24.5 & 0.86 & 2.50 & Sicuro et al., 2012 \\
\hline
\end{tabular}

\section{Conclusions}

Through the statistical analysis, it can be stated with $95 \%$ confidence, when a single metal is considered, all mean metal concentrations among ten species were significantly different $(p<0.05)$. It can be inferred that the mean concentration of a single metal between at least two sea cucumber species was different. Through statistical analysis same result was obtained for all analysed eight metals. In different species, accumulation of different metals was varied. Therefore, it could not be determined in a single species that had a high or a low accumulation of all the studied metals. From the studied species, Holothuriascabra showed a less amount of metal accumulation except mercury than other nine species. It showed the highest accumulation of mercury. The studied can conclude that species did not exceed the maximum allowable legal limit of trace metals and generally 'safe' to human consumption.

\section{Acknowledgement}

This work was supported by the National aquatic Resources Research \& Development authority (NARA) annual research grant to Institute of Post Harvest Technology (IPHT) in 2010. Authors' deepest gratitude is for Dr. D.C.T. Dissanayake of Marine Biological Resources Division (MBRD) of NARA for her support for the sample collection. 


\section{References}

[1] Anonymous, (2007).The gazette of the democratic Socialist Republic of Sri Lanka (Extraordinary), No. 1528/7, December 17, 2007.

[2] AOAC international, (2000). Official Methods of Analysis of the Association of the Official Analysis Chemists, 17th edition.

[3] Beeby, A., (1991).Toxic metal uptake and essential metal regulation in terrestrial invertebrates: A review. In: Newman MC, McIntosh AW, editors. Metal Ecotoxicology: Concepts and Applications. (Chelsea, USA: Lewis Publ, MI, USA). pp. 65-89.

[4] Bertini, I.,Gray, H.B., Stephen, J.L., andValentin, J.S. (1998).Bioinorganic chemistry, ch9 Metals in Medicine $1^{\text {st }}$ south Asian edition.(VinodVasishtha for Viva book private limited). pp. 505-513.

[5] Catharina, Y.W.A., Keshun L. and Huang Y.W. (1999).Asian Food Science and technology,(CRC Press). pp. 389.

[6] Clarck, A.M. and Rowe F.E.W., (1971). A monograph of the existing crinoids. Bulletin of US National Museum. 82: 860.

[7] Denton, G.R.W., Morrison, R.J., Bearden, B.G., Houk, P., Starmer, J.A., and Wood, H.R., (2009). Impact of a coastal dump in a tropical lagoon on trace metal concentrations in surrounding marine biota: A case study from Saipan, Commonwealth of the Northern Mariana Islands (CNMI). Marine pollution bulletin. 58: 424-455.

[8] Dissanayake, D.C.T. and Wijeyaratne, M.J.S. (2007). Studies on the sea cucumber fishery in the North Western coastal region of Sri Lanka. Sri Lanka Journal of Aquatic Science. 12: 19-37.

[9] Dissanayake, D.C.T., Athukorala, S. and Amarasiri C. (2010). Present status of the sea cucumber fishery in Sri Lanka. SPC beche-de-mer information bulletin. 30: 14-20.

[10] Jun, X., (1998). Heavy metal accumulation in tissue/organs of a sea cucumber, Holothurialeucospilota. Journal of Hydrobiologia. 352: $17-23$.

[11] Kumara, P.B.T.P. (2005). Present status of the sea cucumber fishery in the southern Sri Lanka: A resource depleted industry.SPC Beche-de-mer information bulletin. 22: 24-29.

[12] Michel, W., Sandrine, D., Gilles, L., Alessia, M., Rodrigues, Y., and Philippe, D., (2006). Heavy Metals in the Sea Cucumber Holothuriatubulosa (Echinodermata) from the Mediterranean Posidoniaoceanica Ecosystem: Body Compartment, Seasonal, Geographical and Bathymetric Variations. Environmental Bioindicators. 1: 268-285.

[13] Medina, R.G., Carlos, Z.M., Manuel, C.B., and Roberto, P.C., (2004).Concentration the $\mathrm{Cd}, \mathrm{Cr}, \mathrm{Cu}$ and $\mathrm{Pb}$ in sediments and in three species of sea cucumber (class Holothuroidea) from the coast of Yucatan. Mexican Journal of research article engineering. 8: 719.

[14] MOFAR, 2011. Ministry of Fisheries and Aquatic Resources, Sri Lanka, 2011, available at, www.fisheries.gov.lk/statistics.html, [Accessed on June.16, 2012].
[15] Nil, P.O., Suhendan, M.andCandan V. (2004). Effect of the handling procedures on the chemical composition of sea cucumber. Turkish journal of fisheries and aquatic sciences. 4: 71-74.

[16] Pugh, R.S., Becker, R.R. (2001). Sea Turtle Contaminants: A Review with Annotated Bibliography. National Technical Information Service, Virginia, USA, pp. 144.

[17] Tandon, A.M. and Henry M.H. (1873).The world of the sea, published by Casell, Petter and Galpin.

[18] Turkmen, M., Turkmen, A., Tepe, Y., Ates A.,andGokkus, K., (2007). Determination of metal contaminations in seafood from Marmara, Aegean and Mediterranean seas: twelve fish species. Food Chemistry. 108: 794-800.

[19] Sicuro, B., Piccinno, M., Gai F., Abete, M.C., Danieli, A., Dapra, F., Mioletti, S., and Vilella S., (2012). Food quality and safety of Mediterranean sea cucumbers Holothuriatubulosa and Holothuriapolli in Southern Adriatic Sea. Asian journal of animal and veterinary advances. 7 (9): 851-859.

[20] Julshamn, K. and Grahl-Nielsen, O. (1996). Distribution of trace elements from industrial discharges in the Hardangerfjord, Norway: a multivariate data analysis of saithe, flounder and blue mussel as sentinel organisms. MarinePollutionBulletin. 32: 546571.

[21] Luoma, S. N. (1990). Processes affecting metal concentrations in estuarine and coastal marine sediments. In Furrness, R. W. \& P. S. Rainbow (eds) Heavy Metals in the Marine Environment, CRC Press, Inc. Boca Raton: 51-66.

[22] Pacyna, J.M. and Pacyna, E.G. (2001): An assessment of global and regional emissions of trace metals to the atmosphere from anthropogenic sources worldwide. Environment Rev., 9: 269-298.

[23] Adachi, H., Takaaki, I., Shin, T., Tsunemi, K., Shinsuke, H. and Shinsuke, T. (2012). Bioaccumulation of trace elements in marine organisms from deep-waters of Off-Sanninn and Off-Hokuriku, Japan. Interdisciplinary Studies on Environmental Chemistry 6: 169-176

[24] Chen, Z., Lawrence M.M., Christophe, Q., Olivier F.X.D., Robert F.L.S., Peter A. J. and Donald P.W. (2000). High concentrations of complexed metals in the guts of deposit feeders. Limnology and oceanography, 45 (6): 1358-1367

[25] Maria P.I., Henry O., Colin L., Rod F. and Joan W. (2011). Trace element concentrations in nesting flat-back turtles (Natatordepressus). Marine Environmental Research. 71: 10-16

[26] Xing, J. and Chia, F.S. (1997). Heavy metal accumulation in tissue/organs of a sea cucumber, Holothurialeucospilota. Journal of Hydrobiologia. 352: 17-23.

[27] Reilly, C (1991). Metal Contamination of Food. 2nd Edition. Elsevier Applied Science. P 131-147.

[28] Ray, S. and Kiceniuk, J.W. (1994). Cadmium. In: Analysis of contaminants in edible aquatic resources - General considerations: metals, organometallics, tainting and organics. VCH Publishers, USA. p 91-115.

[29] Woodwell, G.M., Craig, P.P. and Johnson, H.A. (1971): DDT in the biosphere: Where does it go? Science, 174: 1101-1107. 